\title{
The Importance of Opening Moves in Classroom Interaction
}

\author{
Siti Aisyah Ginting
}

Faculty of Languages and Arts, State University of Medan, Indonesia

Corresponding Author: Siti Aisyah Ginting, E-mail: aisyah_ginting@yahoo.co.id

\section{ARTICLE INFO}

\section{Article history}

Received: August 04, 2017

Accepted: October 12, 2017

Published: December 30, 2017

Volume: 8 Issue: 6

Advance access: December 2017

Conflicts of interest: None

Funding: None

\begin{abstract}
The analysis of classroom interaction is very important in teaching learning process in order to reach the learning objectives. The purpose of this study was to describe the types of opening moves used by the teacher through the learning process. The research was carried out in Senior High School. The design of the research was descriptive qualitative. The data were collected by observing and recording the teacher's utterances during teaching learning process. The data were analyzed based on Sinclair and Coulthard (1975). The result of the study shows that elicitation and bound types were the dominant ones and followed by re-initiation (i), re-initiation (ii), direct, repeat, inform, listing, and check. One of the opening moves was not applied; it was reinforce. In conclusion, the teacher used all of the types of opening moves but the main focus was in elicitation in the classroom interaction.
\end{abstract}

Key words:

Opening Move,

Classroom Interaction,

Teacher's Talk

\section{INTRODUCTION}

Classroom interaction is the most important part in teaching and learning process since the goal of the teaching and learning can be achieved through the interaction. Especially in language classroom, the interaction made by the teachers through their talks influences the students' language acquisition and vice versa (Long, 1996). Teacher's talk and student's talk are the important components to build the classroom interaction. Classroom interaction occurs since the class begins until the end. Therefore, the intensity of the interaction depends on the teachers. How they vary the interaction in the classroom (Hall \& Walsh, 2002). The learners can learn best way through interaction. Tsui (1995) said that the development and success of a class depends on to a greater extent of the interaction between teacher and students. Students can use all they have already learnt from classroom or from real life situations through the interaction. They also create mutual understandings of their involvement as members in the classroom.

It is assumed that the quality and quantity of teacher talk have many values in young learner's classroom interaction (Moon, 2000). Firstly, it provides language input as language model for children (Pinter, 2006). Secondly, teacher talk supports student talk in practicing the language. Thirdly, the appropriateness of teacher talk can result in a warm classroom atmosphere and informal teacher-student relationship. Since the classroom occurs at the beginning of the classroom until the end, so the teacher holds the rights to open the discourse in the classroom. The opening move or initiation is one of the types of moves, which is the very first point that every teacher must know because the starting point of the interaction itself is the opening move. So, it means that the teacher must be able to apply appropriate opening move in his/her talk in the classroom to create an effective classroom interaction.

In the classroom situation, it is the role of the teacher to open the discourse. If teachers are lack of creativity to open the discourse in the classroom, then, it is predicted that the interaction in the classroom will not run smoothly, which blocks the success of the process of teaching and learning process. Actually, this condition happens because the teachers do not know the types of initiations and their functions. The opening of the discourse in the classroom are realized by ten exchanges: teacher elicit, teacher inform, teacher direct, check, listing, re-initiation (i), re-initiation (ii), check, repeat, reinforce (Sinclair and Coulthard 1975). All of the opening moves are used in different purpose.

Usually in the classroom, teachers open the discourse by using elicitation, for example:

T: Ya. Ok students. This is our new materi. Ini materi baru di kelas kita hari ini. Minggu semalam kita materinya apa? ("This is a new topic in our class, last week hat was our topic?")

SS: Introducing self (only some students answered) 
T: Introducing self. Ini ada yang gak ngudeng ini ya what I mean. Yang saya maksud gak ngerti ya. Apa minggu semalam materi kita? ("Some of you do not understand what I mean. You do not understand what I mean, do you?")

SS: Introduce self (all students)

The example shows that the teacher opens the discourse by using elicitation. Meanwhile to create an effective language classroom, teachers actually can use variation to open the discourse in the classroom, for example:

T: Ya. Ok students. This is our new materi. Ini materi baru di kelas kita hari ini. Tapi sebelumnya coba, jelaskan pelajaran kita minggu lalu! Yang tau saya kasih nilai tambah. Ayo! ("This is a new topic for our class today. But, before that, try to explain our last week topic! For those who know the answer, I will give additional mark. Common!")

S: (raising hand)

From the example above, the teacher uses direction to open the discourse. The purpose was actually the same as in the previous example. However, the teacher used different opening move, which was direction. It can be seen from both examples that in the first example by using elicitation, the teacher got an unclear answer, because the students responded the teacher's elicitation simultaneously. Furthermore, only some of them responded the teacher's elicitation. In the second example, by using direction the teacher could stimulate the student's participation to respond the teacher's opening move. By varying the opening move, teacher could stimulate each student's participation to speak up in the classroom. In fact, teachers tend to open the discourse by using elicitation.

\section{Classroom Interaction}

Interaction is the collaborative exchange of thoughts, feelings, or ideas between two or more people resulting in a reciprocal effect on each other (Brown, 2000:165). He moreover explains that "classroom interaction as the communication between teachers and learners in the classroom so the interaction is the heart of communicative competence, it is what communication is all about". Teacher-student interaction plays an important role in learning since it provides learners with authentic input and feedback because they can establish their roles and relationship (Hall and Walsh, 2002). In other words, they are aware of taking turn to answer, what do they have to say, and how. Dagarin (2004: 128) argues that classroom interaction is "two ways process between the participants in the learning process, the teacher influences the learners and vice versa". All of these may appear because of the language used by teachers and students in the classroom. The use of language in the classroom has been a growing interest in studies of language interaction inside the classroom. For example, Bellack (1966) discussed classroom discourse in terms of four-part framework: structure, solicit, respond, react, Flanders (1970) an analysis of teacher and students talk consisting of category system, Mehan (1979) divides the classroom discourse into three phases, opening phase, instructional phase and closing phase. Hatch (1978) emphasizes the role of interaction in language acquisition, Allwright (1980) analyzes patterns of participation-turn, topics, tasks in language learning and teaching, Tsui (1995) discussed classroom interaction and the effect on participation and learning. Ellis (1994) views the classroom interaction based on the language used in the EFL classroom discourse: 1) mechanical (i.e. no exchange of meaning is involved); 2) meaningful (i.e. meaning is contextualized but there is still no new information to be conveyed); 3) pseudo-communication (i.e. new information is conveyed but in a manner that would be unlikely to occur outside the classroom); 4) real communication (i.e. spontaneous speech resulting from the exchange of opinions, jokes, classroom management etc.). The present study investigated opening moves made by teacher based on Sinclair and Coulthard model (1975) who analyze the classroom discourse known as IRF (Initiation-Response-Feedback).

\section{Sinclair and Coulthard Model}

Sinclair and Coulthard (1975) developed a model for the description of teacher-pupil talk based on a hierarchy of discourse units. The Sinclair and Coulthard model was devised in 1975 and slightly revised in 1992. It consists of five ranks: lesson; transaction; exchange; move and act ( $\mathrm{Ji}$ ang, 2012: 2147).Nicholson (2014:200) states that the Sinclair and Coulthard model proposed to show how interaction in the classroom takes place by taking a linguistic and functional look at discourse. The structure for the Sinclair \&Coulthard model was originally developed through the application of transcripts taken from primary school classroom settings in the 1970's.

Sinclair \& Coulthard's model takes a structural look at classroom conversation by breaking the discourse down into 5 ranks, namely: lesson, transaction, exchange, move and act, which relate hierarchically; each rank is realized by the rank below.In the following presented the 5 ranks:

According to Sinclair and Coulthard (1975), exchanges in the classroom consist of initiation moves (called the opening move), response moves (the answering move), and follow-up moves. IRF structure is characteristic of teacher-led discourse, in which the teacher provides some degree of comment and evaluation.

\section{Types of Opening Moves}

Initiation or opening moves is the opening of discourse that is conducted by teacher. The opening move is realized by ten exchanges: teacher elicit, teacher inform, teacher direct, listing, re-initiation (i), re-initiation (ii), check, repeat, reinforce.

\section{Teacher Elicit}

The most common exchange that the teacher uses is an elicitation. This kind of exchange begins with the teacher asking a question. "The students give their own answer and the teacher gives a response such as follow-up evaluation" (Hellermann, 2003:80).

This category designed to obtain verbal contributions from students. It is very frequently a teacher will use a series of Elicitation exchanges to move the class step by step to a conclusion. The Elicitation exchanges, 


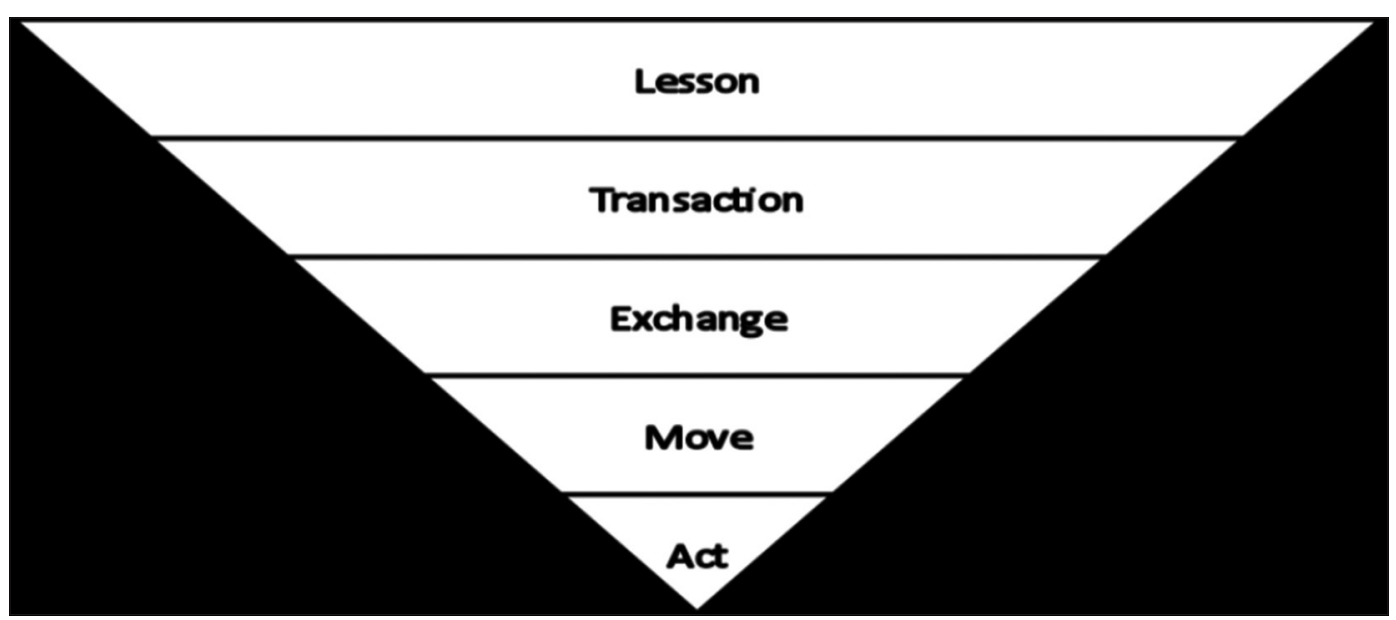

Figure 1. Diagram of Sinclair \& Coulthard's model rank-level, adapted from (Nicholson, 2014)

which occur inside the classroom, have a different function from most occurring outside it. Usually, we ask a question because we do not know the answer. But in classroom situation, when teachers ask a question, very frequently they know the answer. They just want to know whether the students follow the lesson.

2. Teacher Inform

Teacher Inform is an opening move made by teacher to pass on facts, opinions, ideas, or new information. The response usually is an acknowledgement of attention and understanding.

3. Teacher Direct

This category covers all exchanges designed to get the students to do but not to say something (Sinclair and Coulthard, 1992). Therefore, the response from the students is the 'doing' part, which will most likely but not always be a non-verbal response. Even though it is non-verbal, the students respond to the direction the teacher has given. For example:

T: Now, you can do them in any order you like. Let's see if you can sort out the main topic of this paragraph.

\section{$\mathrm{P}: \mathrm{NV}$}

This example shows the teacher is directing the students to complete some sort of activity. The response from the students is non-verbal suggesting that they have acknowledged what the teacher has said. Feedback is not necessary but often occurs, therefore labeling the structure IR (F) (Sinclair and Coulthard, 1992).

4. Listing

Teacher listing is a boundary opening move made by teacher when she withholder evaluation in order to get two or three or more answers from the students to make sure that more than one students knew the answer.

5. Re-initiation (i)

When the teacher gets no response to an elicitation, she/ he can start again using the same or a rephrased question, or he can use one or more of the acts prompt, nomination, clue to re-initiate.

6. Re-initiation (ii)

Re-initiation (ii) is a bound initiation made by teacher when she gets a wrong response to an elicitation, she starts again. There are two major routes open to her: she can stay with the same student and try by Socratic method to work her round to the right answer of she can stay with the same question and move on to another students to re-initiate.

7. Check

At some in most lessons, teachers feel the need to discover how well the students are getting on, whether they can follow what is going on, whether they can hear. To do this, they use a checking move which could be regarded as a subcategory of elicit, except that feedback is not essential, because these are real question to which the teacher does not know the answer.

\section{Reinforce}

Very occasionally there is a bound exchange following a teacher direct. Bound exchanges occur when the teacher has told the class to do something and one student is slow or reluctant or has not fully understood.

9. Repeat

Repeat is a bound initiation from teacher in the communicative situation. There were times when someone did not hear. Even though there was no student admitting to not hearing, teachers do so quite frequently.

10. Bound Initiation

Bound initiation is an initiation made by teacher when she got no response or a wrong response to an elicitation or direction. In this case she started again by repeating or rephrasing the question or move on to another students. When this happened, discourse acts such as 'loop', 'nomination', 'prompt', and 'clue' were expected to appear. A discourse element for these teacher's acts was called 'bound Initiation' $\left(\mathrm{I}^{\mathrm{b}}\right)$ and it might be found in ways of 're-initiation', 'listing', 'reinforce', or 'repeat'.

\section{METHODOLOGY}

This study was conducted by applying descriptive qualitative design. (Bogdan and Biklen, 1992) state that descriptive qualitative design is a research, which has a natural setting as the direct source of the data and the researcher is the key 
instrument. This design was chosen because the fact that the study dealt with language phenomenon as a social element. This study was interviewing and observational case study, because the main data were gathered by applying participant interview and observation. The purpose of this study was to describe the classroom interaction and focused on opening moves made by the teacher. The data of the research were the teacher's utterances, which contained opening moves made by teacher during teaching learning process.

\section{Findings}

Based on the analysis of the interaction between teacher and students during teaching learning process, it was found that from the total 94 opening moves made by teacher appeared in the classroom interaction, the elicit move appeared dominantly 51 times $(54.25 \%)$, direct 6 times $(6.38 \%)$, inform four times $(4.25 \%)$, check four times $(4.25 \%)$, bound 29 times (30.85\%), re-initiation (i) 12 times $(12.76 \%)$, re-initiation (ii) 8 times $(8.51 \%)$, listing 4 times $(4.25 \%)$, and reinforce was not found, repeat 5 times $(5.31 \%)$. For the existences of elicit exchanges which were appeared as the dominant one, it may indicate that teacher usually use questions to manage the classroom interaction because in some classrooms, over half of the class time is taken up by question-and-answer exchanges (Liu and Le, 2012:3).

For the existences of the direct exchanges, they were designed in order to get the students to do and obey the order of the teacher in this case. In the language of the classroom, the teacher is absolutely the authority of the class; there is little need for the teacher to be indirect for the social reasons (Liu and Zhao, 2010:80). It is natural for students to listen to their teacher and follow the teacher's directions.

Meanwhile, the exchange of teacher informs where teacher contributed the facts; opinions, ideas and new information were functioned to convey the information related to the teaching material to the students. As the checking move, it was a way to help teacher to discover how well students are getting on, whether they can follow what is going on, or whether they have understood or not.

In bound initiation exchanges, they were used to stimulate students' response to a previously unanswered question or wrong answer question which can be done by repeating or rephrasing the question or move on to another student.

In term of re-initiation (i) exchanges, the teacher tried to utter the question in the other way or used one or more of the acts prompt, nomination, clue to re-initiate when the teacher got unanswered question from the previous move. Meanwhile, to induce the correct response from the student, teacher did the two major way when she got incorrectly answered in term of re-initiation (ii) exchanges, the first was teacher stayed with the same student and induce the student till the teacher could get the right answer and the second, the teacher moved to another student with the same question.

For the listing exchanges, teacher tried to withholder evaluation in order to get two or three or more answers from the students to make sure that more than one student knew the answer. Repeat exchanges were produced because the teacher used this way in order to look the students whether they listen carefully or not, also to assess student's concentration. The teacher didn't use reinforce exchange at all.

\section{DISCUSSION}

The finding confirms that the most dominant type of opening moves occurs in the classroom to the least one. The teacher used most the opening moves and varied the opening moves except reinforce. As it is found, teacher's elicits are the mostly moves used by the teacher in this study. $54.25 \%$ of the exchange used by the teacher was shown to be eliciting exchanges, which were mostly related to obtain verbal responses from the students. The teacher used elicitation exchanges particularly when she was trying to gain students' participation, which was realized by questioning. Question as a request for information and it is the commonest and most straightforward way to make students to talk in the class. By asking students some questions, the interaction will be motivated quickly and heatedly (Liu and Zhao, 2010). More over $\mathrm{Yu}$ (2009: 152) says that questioning is reported as one of the commonly used strategies, as the success of a class largely depends on questioning and feedback (Yu, 2009:152).

The second highly used type of exchange was shown to be bound exchanges, which were used with proportion of $30.85 \%$ in her talk. Using this type of exchange, the teacher tried to participate with the students in classroom discourse by posing another form of question, which is easier to be comprehended by the students.

Re-initiation (i) exchanges constituted $12.76 \%$ of the total exchange posed by the teacher. Inform, check and listing also account for certain percentage are lower. Using teacher inform, she would like to convey the information to students. These types of exchanges were the types, which were used least by the teacher in this study. The teacher used them in the same proportion of $4.25 \%$ in her talk.

The teacher used teacher direct in $6.38 \%$ of her talk. The teacher has started the opening and students gave their NV response. The listing got the lowest portion about $4.25 \%$ of the total. It is different with re-initiation (i), it is about $8.51 \%$ the teacher used Re-initiation (ii). This is common thing that teacher do to assess the student's confidence about their answers. In another case, it is $5.31 \%$ teacher liked to do repeat exchanges in her classroom. The teacher used this way in order to know the students whether they listen carefully or not, also to assess student's concentration. The teacher did not use reinforce exchange at all.

\section{CONCLUSIONS}

Although most of exchanges posed by the teacher were shown to be eliciting exchange, the teacher seemed to be of those types of teacher who try to gain participation in the classroom. The teacher seemed to be very interested in bound and re-initiation (i), which together constitutes a considerable part of her discourse. By using these types of moves, then she tried to provide a friendly atmosphere in which students feel comfortable in responding their teacher. In order to create interaction between teacher and student, the teacher is supposed to vary the using of opening moves 
and also knows the function of all opening moves. The type of opening moves used by the teacher can have a very important role in constructing a facilitative environment for the successful teaching. The teacher in this study by posing challenging and interesting ways tried to involve the students in classroom discussion by making them participate in long turns.

\section{REFERENCES}

Brown, H.D (2000). Teaching by principles (2 $\left.{ }^{\text {nd }} E d\right)$. London: Longman.

Cazden, C. B (2001). Classroom discourse: The language of teaching and learning. Netherlands: Heinimann Educational Books.

Cockayne, M. (2010).Applying the Sinclair and Coulthard Model of Discourse Analysis to a students-centered EFL.

Coulthard, M. and Brazil, D.C. (1992). 'Exchange structure'. In Coulthard, M.(Ed) 1992. Advances in spoken discourse analysis. 50-78. London: Routledge.
Dailey, A. (2010). An Analysis of Classroom Discourse: The Usefulness of Sinclair and Coulthard's Rank Scale in a Language Classroom

Ellis, R. (1994). The Study of Second Language Acquisition. Oxford: Oxford of University Press.

Hall, J., \& Walsh, M. (2002). Teacher-student interaction and language learning. Annual Review of Applied Linguistics, 22, 186-203

Jiang, X. (2012). A Study of College English Classroom Discourse. Journal: Theory and Practice in Language Studies, 2(10), 2146-2152. Findland: Academy.

Mehan, H. (1979). Learning Lessons: Social Organizationin the Classroom. Cambridge, Mass: Harvard University Press.

Nicholson, S.J. (2014). An Impetus for Change: Classroom Analysis Using Sinclair and Coulthard's Model of Spoken Discourse, 6(2). South Korea: Hankuk University of Foreign Studies.

Tsui, A.B.M. (1995). Introducing Classroom Interaction. London: Penguin. 